\title{
Motivating Group Learning in Farmer Community
}

\author{
Mustofa Kamil, Yanti Shantini, Cucu Sukmana \\ Department of Non Formal Education \\ Faculty of Education \\ Universitas Pendidikan Indonesia \\ Bandung, Indonesia \\ mustofa.kamilun@upi.edu
}

\begin{abstract}
Dynamics of learning in the empowerment of farmers is one of the forces and motion are shown with the active involvement of farmers and businesses in the learning process to change attitudes and behaviors to enhance the independence of farming and quality of life. This study aimed to describe the empowering process through learning in group by using the social media facility like Instagram and Facebook for selling commodity product. Conducted in Pagerwangi Village for 20 farmer divided in 4 small group learning. The result of the study are the dynamic of learning are increased which showed by high of attendance of farmer, participation along the training process and willingness to come in facilitating program.
\end{abstract}

Keywords - Empowerment of farmers, group dynamics, selfsufficiency farming

\section{INTRODUCTION}

Farmer empowering process is a condition that can be grown through a process of education that is giving strength or power. Empowerment of farmers is considered important for the development of agriculture, farmers are resource development plays a key player in developing the farming operation. According to [1] empowerment meant as (1) providing the opportunity to freely choose various alternatives and make a decision, in accordance with the level of awareness, ability, and desire, and (2) providing the opportunity to learn from their successes and failures in give response to changes, so it is able to control his future.

Such conditions do not necessarily show up but in many cases to be deliberately grown through group dynamics. To support the involvement of the group in the empowerment of farmers, need for improvement of the policy administration functions in the agricultural extension system. These functions [2] and [3] through the research function, function extension and farming function which in this case is a farmer groups as users of new ideas. [4] suggested that the function of leadership of the group, is an important factor that characterizes the performance of the group. [5] Stated that the leadership of the group can be seen as anything that can help the group to achieve optimal results. On the basis of the changes that occur during this time, as well as the challenges of the present and the future, the implementation of these functions need to be adjusted towards the creation of a policy climate that supports efforts to empower farmers to be more independent and in addressing these challenges

Concerning learning in a group of farmer, sociocultural theory states that learning is a process in the sense of participation rather than something that happened in the thinking of an individual. Learning is a "nexus of relations" were distributed in groups working together. [6], but we have to remember that the success of group learning is depending on how is the group is organized, what the task are, who participate and how the group is held accountable. [7]

Based on that idea, the problem is how social psychological characteristics of farmers in farmer empowerment program based on group dynamics? How learning steps farmer empowerment program based on group dynamics? what factors inhibiting and supporting the empowerment of farmers based on group dynamics?

\section{METHOD}

This research method is a case study with a qualitative approach. Research was conducted on a group of farmers in the village Pagerwangi as many as 20 people, divided into 4 groups. Farmers were trained for 2 months on the use of social media in the form of Instagram and Facebook used as media in marketing agricultural products. To measure the achievement of learning outcomes do pretest and post test. In addition to the assays used data collection techniques are also used interviews and observations to obtain data about the psychological conditions, and the difficulties experienced by farmers for participating in learning activities.

\section{RESULT AND DISCUSSION}

\section{A. Social psychological characteristics of farmers in the program Farmer Empowerment Group Dynamics Based Farming For Improved Self-Reliance}

Farmers have diverse characteristics, these characteristics can be a social character, cultural, demographic character, psychological as well as the character of the economic conditions of the farmers themselves. These character traits that distinguish the type of farmer's behavior in certain situations. Social psychological characteristics observed in this study were age, educational background, acreage, individual perceptions of farmers and farming experience.

According to BPS (2015), based on the composition of the population, grouped into 3 age $0-14$ years of age are considered as a group have not been productive population, the population group aged 15-64 years as a productive group and age group 65 years and above as groups that are no longer productive.

Distribution of life characteristics of farmers based on survey results revealed that $55.00 \%$ of the farmers are in the range of 
age $>35-55$ years. This indicates that most respondents are in the productive age category, the age of the respondents associated with innovations, someone at the age of non-productive would be less likely to accept innovation, otherwise someone with operational life will be easier and faster accept innovation. This is in accordance with the opinion of [8] that more and more young farmers usually have a passion to want to know what they do not know, so they try to more quickly make the adoption of innovations, although usually they are still inexperienced in the matter of the adoption of such innovations.

The educational background of a number of years of formal schooling, which reached the farmers to formal education. Farmer education respondents classified in the low category for $40.00 \%$ in the range of $0-6$ years or equivalent only primary school graduates. These results indicate that farmers often lack sufficient knowledge to be able to understand their problems and less appropriate to resolve the problems faced in order to achieve the expected goals. According [9] the level of education a person can change the mindset, the better reasoning power, so that the longer the person's education will be more rational. The land area farmers based on the results of the study are in the range of 0.10 to 0.60 hectares of land belonging to farmers land area narrow. According [10], the land area farm income determined, living standards and the degree of well-being of farm households.

Experience farmers farming based on research results has more than 30 years, it shows that farmers are very experienced in the cultivation of crops. This experience is the basic capital in accepting innovations to increase productivity of crops that they manage. According [11] experience is the knowledge that a person experiences within an unspecified time. Pleasant and satisfying experience will have a positive impact to continue adopting an innovation.

Psychologically the individual's perception of farmers to a farmer empowerment program based on group dynamics to increase the independence of farming greatly influenced by the ability of giving meaning or significance of that program, the individual experiences, feelings, beliefs, knowledge of innovation, ability to think, reference sources and motivation for learning.

According [12] changes the attitude of farmers led to changes in the needs of farmers. Farmers need now is a marketing strategy as a result of their farm-level impacts decent incomes and the availability of fresh money as an instrument to actualize themselves, develop themselves and defend themselves

\section{B. Step-by-step learning program Farmer Empowerment Group Dynamics Based Farming For Improved Self- Reliance}

Step-by-step learning program based on group dynamics to empower farmers to increase the independence of farming as follows:

1. Set up a learning tool farmer empowerment program based group dynamics to increase the independence of farming them; a) Free lesson farmer empowerment program, b) Preparation of teaching materials, c) Preparation Instructor, d) participants / members of farmer group.
2. Implementation of the training program based on group dynamics to empower farmers to increase the independence of the farm consists of a dynamic collaboration, learning dynamics and business dynamics. As for the aspects that made the research in this training, including: a) the purpose of the group, b) a group structure, c) the functions and duties of the group, d) development group, e) is the group, and f) the effectiveness of the group.

3. The implementation of farmer empowerment program based mentoring group dynamics to increase the independence of farming, consisting of: home visits and field, office visits, public meetings, discussion meetings, courses / coaching agriculture, field trips.

\section{Inhibiting factors and supporting the empowerment of} farmers based on group dynamics to increase the independence of farming.

\section{Obstacles}

Internal: the low quality of human resources. External: erratic weather and the limited capacity of agricultural resources.

\section{Supporting Factor}

Internal: the empowerment of farmers and the support of the Regional Government of West Bandung regency. External: aid to ease the burden on farmers.

\section{CONCLUSION}

From the discussion above, a number of conclusions that the characteristics of the age of the farmer based on the survey results revealed that $55.00 \%$ of the farmers are in the range of age $>35-55$ years. This indicates that most respondents are in the productive age categories. The educational background of the respondents classified in the low category for $40.00 \%$ in the range of 0-6 years. These results indicate that farmers often lack sufficient knowledge to be able to understand their problems and less appropriate to resolve the problems faced in order to achieve the expected goals. Acreage results of the study are in the range 0.10 to 0.60 hectares of land classified as land area farmers narrow. The individual's perception of farmers is very influenced by the ability of giving meaning or significance of the program, the individual experiences, feelings, beliefs, knowledge of innovation, ability to think, reference sources and motivation for learning. Farming experience based on research results has more than 30 years, it shows that farmers are very experienced in the cultivation of crops.

\section{REFERENCES}

[1] Bryant, Corralie and Louis G White, 1982, Managing Development in Third Word, Prentice Hall, Englewood Cliff. New Jersey

[2] Lionberger Havelock, Ronald. 1973. The Change Agentfs Guide to Innovation in Education. Educational Technology Publication Englewood Cliffs, New Jersey.

[3] Prabowo, Tjitropranoto. 1990. Komunikasi Penelitian Pertanian. Perpustakaan Pertanian dan Biologi. Bogor

[4] Lewin, K., R. Lippit, dan R.K. White. (1939). Pattern of Aggressive behavior in Experimentally created Social Climates. Journal of Social Psyschology 10.

[5] Cartwright, D dan A. Zander. 1968. Group Dynamics: Research and Theory. Harper \& Row Publishers. New York 
[6] Hager, P. (2014). Practice and Group Learning. Educational Philosophy and Theory, $46(6)$

584-599. http://doi.org/10.1080/00131857.2013.779212

[7] Marx, R. W., Soloway, E., \& Krajcik, J. (1996). Learning With Peers:, (November), 37-40

[8] Soekartawi. (2005). Agroindustri Dalam Perspekstif Sosial Ekonomi. Grafindo Persada. Jakarta
[9] Saridewi,R. dkk. 2010. Hubungan antara Peran Penyuluh dan Adopsi Teknologi oleh Petani terhadap peningkatan Produksi Padi di Kabupaten Tasikmalaya. STPP. Bogor.

[10] Hernanto, F. 1993. Ilmu Usaha Tani. Penerbit swadaya. Jakarta.

[11] Padmowihardjo,S. 1999. Psikologi Belajar Mengajar. Jakarta Universitas Terbuka

[12] Puspadi, K., 2002. Rekonstruksi Sistem Penyuluhan Pertanian. Disertasi. Program Pasca Sarjana Institut Pertanian Bogor. 